\title{
Fruit quality preservation of 'Laetitia' plums under controlled atmosphere storage
}

\author{
CRISTIANO ANDRÉ STEFFENS ${ }^{1}$, CASSANDRO V.T. DO AMARANTE ${ }^{1}$, \\ ERLANI O. ALVES ${ }^{1}$ and AURI BRACKMANN ${ }^{2}$ \\ ${ }^{1}$ Universidade do Estado de Santa Catarina, Centro de Ciências Agroveterinárias, \\ Avenida Luiz de Camões, 2090, 88520-000 Lages, SC, Brasil \\ ${ }^{2}$ Universidade Federal de Santa Maria, Av Roraima, 1000, Cidade Universitária, \\ Bairro Camobi, 97105-900 Santa Maria, RS, Brasil
}

Manuscript received on June 6, 2013; accepted for publication on November 1, 2013

\begin{abstract}
The objective of this study was to evaluate the effect of controlled atmosphere (CA) on quality preservation of 'Laetitia' plums, mainly on internal breakdown, in order to determine the best CA storage conditions. Two experiments were carried out one in 2010, and another in 2011. In 2010, besides cold storage (CS; $\left.21.0 \mathrm{kPa} \mathrm{O}_{2}+0.03 \mathrm{kPaCO}_{2}\right)$, the fruits were stored under the following CA conditions $\left(\mathrm{kPa} \mathrm{O}_{2}+\mathrm{kPa} \mathrm{CO}_{2}\right)$ : $1+3,1+5,2+5,2+10$, and $11+10$. In 2011, the fruits were stored under CS and CA of $1+0,1+1,2+1$, and $2+2$. The fruit stored under different CA conditions had lower respiration and ethylene production, better preservation of flesh firmness, texture and titratable acidity, lower skin red color, and lower incidence of skin cracking than the fruit in CS. In 2010, the fruit under CA with $2+5,1+5$, and $1+3$ had a pronounced delay in ripening, although it exhibited a high incidence of internal breakdown. In 2011, the CA conditions with $2+1$ and $2+2$ provided the best delay in ripening and a reduced incidence of internal breakdown. The best CA condition for cold storage (at $0.5^{\circ} \mathrm{C}$ ) of 'Laetitia' plums is $2 \mathrm{kPa} \mathrm{O}_{2}+2 \mathrm{kPa} \mathrm{CO}_{2}$.
\end{abstract}

Key words: Prunus salicina, postharvest, ripening, physiological disorder.

\section{INTRODUCTION}

Ripening of plums is extremely fast and their harvest season does not usually last more than 20 days, thus they produce a large amount of fruit within a short period of time. Nevertheless, the production period may be prolonged by storage. Controlled atmosphere (CA) is the storage system which allows for better preservation of the fruit quality due to a more pronounced reduction in the fruit metabolism.

The storage of plums under CA is a subject which still not well explored subject and there

Correspondence to: Cristiano André Steffens

E-mail: steffens@cav.udesc.br is little information on this storage system for 'Laetitia' plums. However, it has been verified that some plum and peach cultivars present better quality during storage under this system due to the reduction of chilling injuries and preserving the physicochemical features (Sestari et al. 2008, Singh and Singh 2013).

Van de Geijn (1993) recommends a $0^{\circ} \mathrm{C}$ temperature and a CA storage of $3 \mathrm{kPa} \mathrm{O}_{2}$ and 7 $\mathrm{kPa} \mathrm{CO}_{2}$ for European plums. Singh and Singh (2012, 2013), in Japanese plums, observed firmer flesh in 'Blackamber' plums stored under CA of 1 to $2.5 \mathrm{kPa} \mathrm{O}_{2}$ and $3 \mathrm{kPa} \mathrm{CO}_{2}$. In peaches, the $\mathrm{CA}$ of 
$2 \mathrm{kPa} \mathrm{O}_{2}$ and $5 \mathrm{kPa} \mathrm{CO}_{2}$ reduces internal breakdown without negatively affecting the physicochemical attributes of the fruit (Brackmann et al., 2007).

A previous work which assessed the effect of CA on the quality of 'Laetitia' plums (Alves et al. 2010) verified a delay in fruit ripening, and the condition presenting the best results was of $2 \mathrm{kPa}$ $\mathrm{O}_{2}+5 \mathrm{kPa} \mathrm{CO}$. However, the authors verified a high internal breakdown incidence, concluding that storing the fruit under CA with lower levels of $\mathrm{O}_{2}$ or $\mathrm{CO}_{2}$ could improve storage without the internal breakdown incidence. Steffens et al. (2009) observed that, under modified atmosphere, inappropriate combinations of $\mathrm{O}_{2}$ and $\mathrm{CO}_{2}$ induce the development of internal breakdown. Storage atmosphere composition is an important factor affecting potential storage life, susceptibility to physiological disorders and overall quality of the fruit (Singh and Singh 2012).

The objective of this study was to evaluate the effect of controlled atmosphere (CA) on quality preservation of 'Laetitia' plums, mainly on internal breakdown, in order to determine the best CA storage conditions.

\section{MATERIALS AND METHODS}

The 'Laetitia' plums used in the 2010 and 2011 experiments were harvested at a commercial orchard located in Lages, SC. They were then taken to the laboratory, where the fruits were selected, and those with mechanical damages or presenting defects, were eliminated. Subsequently, the experimental units were homogenized.

The experimental design used for both experiments was completely randomized with four repetitions, each repetition with 30 plums. The treatments evaluated are described in Table I. $\mathrm{CO}_{2}$ level in the treatments with $0 \mathrm{kPa}$ remained less than $0.1 \mathrm{kPa}$.

In all conditions, the fruits were stored at $0.5^{\circ} \mathrm{C} \pm 0.1^{\circ} \mathrm{C}$ and $96 \pm 2 \%$ RH in experimental minichambers with $180 \mathrm{~L}$ capacity with variations
TABLE I

Storage conditions $\left(\mathrm{O}_{2}+\mathrm{CO}_{2} ; \mathrm{kPa}\right)$ evaluated in both experiments (2010 and 2011).

\begin{tabular}{|c|c|c|c|c|}
\hline \multicolumn{5}{|c|}{ Treatments } \\
\hline & \multicolumn{2}{|c|}{2010} & \multicolumn{2}{|c|}{2011} \\
\hline & $\mathrm{O}_{2}(\mathrm{kPa})$ & $\mathrm{CO}_{2}(\mathrm{kPa})$ & $\mathrm{O}_{2}(\mathrm{kPa})$ & $\mathrm{CO}_{2}(\mathrm{kPa})$ \\
\hline $\begin{array}{c}\text { Cold } \\
\text { storage }\end{array}$ & 21.0 & 0.03 & 21.0 & 0.03 \\
\hline \multirow{5}{*}{$\begin{array}{l}\text { Controlled } \\
\text { atmosphere }\end{array}$} & 1.0 & 3.0 & 1.0 & 0.0 \\
\hline & 1.0 & 5.0 & 1.0 & 1.0 \\
\hline & 2.0 & 5.0 & 2.0 & 1.0 \\
\hline & 2.0 & 10.0 & 2.0 & 2.0 \\
\hline & 11.0 & 10.0 & 2.0 & 1.0 \\
\hline
\end{tabular}

tolerated for $0.1 \mathrm{kPa} \mathrm{O}_{2}$ and $\mathrm{CO}_{2}$. The partial pressures of gases in the treatments with low $\mathrm{O}_{2}$ and high $\mathrm{CO}_{2}$ were obtained from the dilution of $\mathrm{O}_{2}$ into the storing environment with injected $\mathrm{N}_{2}$ (pull down) from a nitrogen generator which uses the "Pressure Swing Adsorption" (PSA) principle and subsequent injection of $\mathrm{CO}_{2}$ from high pressure cylinders, up to the level previously established for the treatment. The partial pressures determined for the gases under the different storage conditions, which varied according to the fruit respiration, underwent maintenance daily. Electronic $\mathrm{O}_{2}$ and $\mathrm{CO}_{2}$ 'Agri-datalog' analyzers were used for monitoring, subsequently corrected until the preset levels were reached. The $\mathrm{O}_{2}$ consumed by respiration was replaced by atmospheric air injection into the minichambers, and the excessive $\mathrm{CO}_{2}$ was absorbed by a potassium hydroxide solution (40\%), though which the air in the storage environment was passed. In storage conditions with $0 \mathrm{kPa}$ of $\mathrm{CO}_{2}$, sachets were placed with moisturized whitewash $(2,000 \mathrm{~g}$ per minichambers $)$ for $\mathrm{CO}_{2}$ absorption. After 60 days of storage, the samples were divided into two subsamples of 15 fruits, one for analysis upon leaving the chamber, and the other for analysis after four days of shelf life (exposure to ambient conditions; $\left.20 \pm 2{ }^{\circ} \mathrm{C} / 60 \pm 5 \% \mathrm{RH}\right)$. The variables analyzed in both experiments were respiration and ethylene production rates, titratable acidity (TA), soluble solids (SS), flesh firmness, 
texture (flesh penetration and fruit compression forces), red color index (RCI), skin color and the incidence of cracking, rottenness and internal breakdown. The intensity of internal breakdown was also analyzed in the 2011 experiment.

The respiration and ethylene production rate values, TA, SS, flesh firmness, skin color [hue angle, $h^{\circ}$ in values from 0 (red); 90 (yellow) and 180 (green)] and the incidence of internal breakdown (\%) were determined as described by Argenta et al. (2003). Ethylene production and respiration rates calculations were conducted according to that proposed by Banks et al. (1995).

Texture attributes $(\mathrm{N})$ were analyzed with a texturometer electronic TAXT-Plus ${ }^{\circledR}$ (Stable Micro Systems Ltd., UK). To quantify the force to flesh penetration was used a probe trial, model PS2, with $2 \mathrm{~mm}$ of the diameter, which was introduced into the flesh at a depth of $5 \mathrm{~mm}$ without removal of the epidermis. To quantify the strength for compression of the fruit was used flat platform, model $\mathrm{P} / 75$, with $75 \mathrm{~mm}$ of diameter, applying compression to a deformation of $5 \mathrm{~mm}$ on the surface of the fruit. In both texture attributes evaluated, the speeds pre-test, test and post-test were 30,5 and $30 \mathrm{~mm} \mathrm{~s}^{1}$, respectively.

Red color index (RCI) was determined by assessing the fruit surface covered with red color, and graded from 1 to $4(0-25 \%, 26-50 \%, 51-75 \%$ and $76-100 \%$ of the surface of the fruit with red colored for the index 1, 2, 3 and 4, respectively).

The incidence of cracking (\%) was verified by counting the fruit presenting skin cracking.

The incidence of rottenness (\%) was assessed by counting the fruit presenting lesions larger than $5 \mathrm{~mm}$ in diameter with pathogen infection characteristics.

The intensity of internal breakdown was assessed by means of a Minolta colorimeter model CR 400 in the central region of the flesh. The results were shown in luminosity $[L$, in values from 0 (black) to 100 (white)].
The data were submitted for analysis of variance (ANOVA). Data expressed in percentages were transformed by arcsine formula $[(\mathrm{x}+0.5) / 100]^{1 / 2}$ prior to the submission to ANOVA. The Tukey test $(p<0.05)$ was adopted to compare the means.

\section{RESULTS AND DISCUSSION}

\section{EXPERIMENT}

Before storage, the plums presented the following ripening attributes: flesh firmness of $42 \mathrm{~N}, 9.3^{\circ} \mathrm{Brix}$ SS and TA of $31.2 \mathrm{meq} 100 \mathrm{~mL}^{-1}$.

Upon exiting the chamber, the fruit stored under CA presented lower respiration and ethylene production rates (Table II). After four days of exposure to room temperature, no differences were observed between the treatments in terms of respiration rate (Table II). However, in terms of ethylene production, the fruit stored under CS presented a higher rate than under CA (Table II). This effect of the CA is due to the low $\mathrm{O}_{2}$ and high $\mathrm{CO}_{2}$ levels and has been observed in other studies (Fonseca et al. 2002, Steffens et al. 2007a).

The respiration rate upon exiting the chamber was lower in the fruit stored under $1 \mathrm{kPa} \mathrm{O}_{2}+5$ $\mathrm{kPa} \mathrm{CO}_{2}$ and $2 \mathrm{kPa} \mathrm{O}_{2}+10 \mathrm{kPa} \mathrm{CO}$ (Table II). The reduction in respiration activity due to low $\mathrm{O}_{2}$ is caused by the decrease in the activity of several oxidases such as cytochrome oxidase, polyphenoloxidase, ascorbic acid oxidase and glycolic acid oxidase. High $\mathrm{CO}_{2}$ levels can reduce respiration and inhibit the glycolytic route, acting on the phosphofructokinase and the cycle of tricarboxylic acids, affecting the succinate oxidase as well as reducing the action of ethylene on enzymes involved in the respiration process (Fonseca et al. 2002).

The lowest ethylene production rate, upon leaving the chamber, was observed on the fruit stored under $2 \mathrm{kPa} \mathrm{O}_{2}+10 \mathrm{kPa} \mathrm{CO}$ (Table II). However, after four days under ambient conditions, there were no differences between the CA conditions. 
TABLE II

Respiration and ethylene production rates, flesh firmness and texture attributes in 'Laetitia' plums stored at $0.5^{\circ} \mathrm{C}$ under different atmospheres for 60 days and another four days under ambient conditions $\left(20 \pm 2^{\circ} \mathrm{C} / 60 \pm 5 \% \mathrm{RH}\right)$, Lages, SC, Brazil, 2010.

\begin{tabular}{|c|c|c|c|c|c|}
\hline \multirow{2}{*}{$\begin{array}{l}\text { Atmosphere } \\
\mathrm{O}_{2}+\mathrm{CO}_{2}(\mathrm{kPa})\end{array}$} & \multirow{2}{*}{$\begin{array}{l}\text { Respiration rate } \\
\left(\mathrm{nmol} \mathrm{CO} \mathrm{Cg}^{-1} \mathrm{~s}^{-1}\right)\end{array}$} & \multirow{2}{*}{$\begin{array}{l}\text { Ethylene production } \\
\text { rate }\left(\mathrm{pmol} \mathrm{kg}^{-1} \mathrm{~s}^{-1}\right)\end{array}$} & \multirow{2}{*}{$\begin{array}{l}\text { Flesh firmness } \\
\text { (N) }\end{array}$} & \multicolumn{2}{|c|}{ Texture attributes } \\
\hline & & & & $\begin{array}{l}\text { Flesh penetration } \\
\text { force }(\mathrm{N})\end{array}$ & $\begin{array}{c}\text { Fruit compression } \\
\text { force }(\mathrm{N})\end{array}$ \\
\hline & \multicolumn{5}{|c|}{ Chamber outlet } \\
\hline $21+0.03$ & $775.6 \mathrm{a}$ & $5.53 \mathrm{a}$ & $16.9 \mathrm{~d}$ & $1.11 \mathrm{~b}$ & $42.8 \mathrm{~d}$ \\
\hline $1+3$ & $527.3 \mathrm{~b}$ & $0.88 \mathrm{c}$ & $35.6 \mathrm{abc}$ & $2.56 \mathrm{a}$ & $78.3 \mathrm{abc}$ \\
\hline $1+5$ & $114.1 d$ & $1.16 \mathrm{c}$ & $36.9 \mathrm{ab}$ & $2.47 \mathrm{a}$ & $86.3 \mathrm{ab}$ \\
\hline $2+5$ & $529.6 \mathrm{~b}$ & $0.96 \mathrm{c}$ & $40.5 \mathrm{a}$ & $2.49 \mathrm{a}$ & $101.2 \mathrm{a}$ \\
\hline $2+10$ & $209.1 \mathrm{~d}$ & $0.37 \mathrm{~d}$ & $30.2 \mathrm{c}$ & $2.23 \mathrm{a}$ & $77.3 \mathrm{bc}$ \\
\hline $11+10$ & $450.1 \mathrm{c}$ & $2.90 \mathrm{~b}$ & $33.7 b c$ & $2.02 \mathrm{a}$ & $62.5 \mathrm{bcd}$ \\
\hline \multirow[t]{2}{*}{$\mathrm{CV}(\%)$} & 15.6 & 11.7 & 8.7 & 12.4 & 16.4 \\
\hline & \multicolumn{5}{|c|}{ After four days of shelf life } \\
\hline $21+0.03$ & $498.4 \mathrm{a}$ & $15.6 \mathrm{a}$ & $12.2 b$ & $0.87 \mathrm{~b}$ & $32.0 \mathrm{~b}$ \\
\hline $1+3$ & $352.9 \mathrm{a}$ & $5.1 \mathrm{~b}$ & $33.8 \mathrm{a}$ & $2.04 \mathrm{a}$ & $74.3 \mathrm{a}$ \\
\hline $1+5$ & $419.4 \mathrm{a}$ & $7.0 \mathrm{~b}$ & $37.3 \mathrm{a}$ & $2.28 \mathrm{a}$ & $74.6 \mathrm{a}$ \\
\hline $2+5$ & $362.1 \mathrm{a}$ & $3.4 \mathrm{~b}$ & $35.8 \mathrm{a}$ & $2.17 \mathrm{a}$ & $80.4 \mathrm{a}$ \\
\hline $2+10$ & $350.3 \mathrm{a}$ & $7.0 \mathrm{~b}$ & $32.4 \mathrm{a}$ & $2.00 \mathrm{a}$ & $74.5 \mathrm{a}$ \\
\hline $11+10$ & $362.7 \mathrm{a}$ & $6.1 \mathrm{~b}$ & $34.4 \mathrm{a}$ & $2.25 \mathrm{a}$ & $67.1 \mathrm{a}$ \\
\hline CV (\%) & 15.1 & 29.2 & 8.7 & 12.0 & 11.5 \\
\hline
\end{tabular}

*Averages followed by the same letters in the columns were not different from one another according to the Tukey test ( $\mathrm{p}<0.05)$.

The lower ethylene production rate could be related to the lower ACC oxidation due to low $\mathrm{O}_{2}$ and/ or to the inhibiting effect of $\mathrm{CO}_{2}$ on the ethylene capacity of inducing autocatalysis (Blankenship and Dole 2003).

Flesh firmness was higher in fruit stored under CA than in fruit stored under air conditions, at chamber opening and after four days of exposure to ambient conditions (Table II). Similar results were found in work with stone fruit, such as 'Maciel' peaches (Sestari et al. 2008). Amongst the storage conditions, upon leaving the chamber, the highest values for flesh firmness were found with $2.0 \mathrm{kPa}$ $\mathrm{O}_{2}+5.0 \mathrm{kPa} \mathrm{CO}, 1.0 \mathrm{kPa} \mathrm{O}+5.0 \mathrm{kPa} \mathrm{CO}$ and $1.0 \mathrm{kPa} \mathrm{O} \mathrm{O}_{2}+3.0 \mathrm{kPa} \mathrm{CO}$ (Table II). This result is in accordance with Streif (1995), who states that partial pressures of $\mathrm{O}_{2}$ between 1.0 and $3.0 \mathrm{kPa}$ are more appropriate for storing plums under $\mathrm{CA}$. Nevertheless, the CA condition with $2.0 \mathrm{kPa} \mathrm{O}_{2}+$ $10.0 \mathrm{kPa} \mathrm{CO}$, in this study, presented the worst results among the $\mathrm{CA}$ conditions. These results disagree with Streif (1995), who considers partial pressures between $8.0 \mathrm{kPa}$ and $12.0 \mathrm{kPa}$ as ideal for storing plums under CA. Singh and Singh (2012, 2013) observed a positive effect of the CA condition of $1.0 \mathrm{kPa} \mathrm{O}_{2}+3.0 \mathrm{kPa} \mathrm{CO}$ in maintaining the flesh firmness in 'Blackamber' plums. This points out a difference in the behavior of different plum cultivars under CA conditions, which explains the difference in the results found in this study and the ones found by other authors regarding the recommended partial pressures of $\mathrm{O}_{2}$ and $\mathrm{CO}_{2}$ (Streif et al. 1995, Singh and Singh 2012, 2013).

The texture attributes assessed, flesh penetration and fruit compression force, presented higher values in the fruit stored under CA upon leaving the chamber and after four days of ambient conditions (Table II). These results are in agreement with those observed by Singh and Singh (2013), regarding the effectiveness of CA in maintaining the flesh consistency. The effect of $\mathrm{CA}$ on the texture attributes can be related to its 
influence on the reduction of ethylene action and biosynthesis, reducing the activity of hydrolytic enzymes responsible for the breakdown of the cell wall components. Majumder and Mazumdar (2002) observed a positive correlation between the increase in the polygalacturonase enzyme activity and the evolution of ethylene in fruit.

The fruit stored under CA presented less skin coverage with red color (lower red color index values) upon leaving the chamber, as well as a less intense redness (higher $h^{o}$ values) upon exiting the chamber and after four days of exposure to ambient conditions (Table III). As observed for flesh firmness and texture, the maintenance of skin color in fruit are related to a decreased ethylene biosynthesis and action under CA storage, since the change in color during plum ripening depends on the action of this phytohormone (Argenta et al. 2003).

TABLE III

Red color index (RCI) and hue angle $\left(h^{\circ}\right)$ of the skin, titratable acidity and internal breakdown in 'Laetitia' plums stored at $0.5^{\circ} \mathrm{C}$ under different atmospheres for 60 days and four days under ambient conditions $\left(20 \pm 2^{\circ} \mathrm{C} / 60 \pm 5 \% \mathrm{RH}\right)$, Lages, SC, Brazil, 2010.

\begin{tabular}{|c|c|c|c|c|c|}
\hline \multirow{2}{*}{$\begin{array}{c}\text { Atmosphere } \\
\mathrm{O}_{2}+\mathrm{CO}_{2}(\mathrm{kPa})\end{array}$} & \multirow{2}{*}{$\begin{array}{l}\mathrm{RCI} * \\
(1-4)\end{array}$} & \multicolumn{2}{|c|}{$h^{o}$ of the skin } & \multirow{2}{*}{$\begin{array}{l}\text { Titratable acidity } \\
\left(\mathrm{meq} 100 \mathrm{~mL}^{-1}\right)\end{array}$} & \multirow{2}{*}{$\begin{array}{c}\text { Internal breakdown } \\
(\%)\end{array}$} \\
\hline & & Least red side & Reddest side & & \\
\hline & \multicolumn{5}{|c|}{ Chamber outlet } \\
\hline $21+0.03$ & $3.51 \mathrm{a}$ & $29.0 \mathrm{~b}$ & $66.1 \mathrm{~b}$ & $12.4 \mathrm{~d}$ & $69.7 \mathrm{c}$ \\
\hline $1+3$ & $2.84 b$ & $35.6 \mathrm{a}$ & $91.2 \mathrm{a}$ & $19.4 \mathrm{a}$ & $53.9 \mathrm{c}$ \\
\hline $1+5$ & $2.51 \mathrm{~b}$ & $39.7 \mathrm{a}$ & $94.1 \mathrm{a}$ & $18.0 \mathrm{ab}$ & $79.0 \mathrm{bc}$ \\
\hline $2+5$ & $2.71 b$ & $38.1 \mathrm{a}$ & $87.7 \mathrm{a}$ & $20.2 \mathrm{a}$ & $56.6 \mathrm{c}$ \\
\hline $2+10$ & $2.57 \mathrm{~b}$ & $39.4 \mathrm{a}$ & $91.6 \mathrm{a}$ & $15.9 \mathrm{bc}$ & $95.1 \mathrm{ab}$ \\
\hline $11+10$ & $2.45 b$ & $38.3 \mathrm{a}$ & $82.8 \mathrm{a}$ & $14.8 \mathrm{c}$ & $98.3 \mathrm{a}$ \\
\hline \multirow[t]{2}{*}{ C.V. $(\%)$} & 6.5 & 7.2 & 7.4 & 7.8 & 15.7 \\
\hline & \multicolumn{5}{|c|}{ After four days of shelf life } \\
\hline $21+0.03$ & $3.91 \mathrm{a}$ & $23.1 \mathrm{~b}$ & $35.3 b$ & $10.4 d$ & $84.7 \mathrm{a}$ \\
\hline $1+3$ & $3.39 \mathrm{a}$ & $30.6 \mathrm{a}$ & $61.4 \mathrm{a}$ & $19.6 \mathrm{a}$ & $48.8 \mathrm{c}$ \\
\hline $1+5$ & $3.36 \mathrm{a}$ & $30.3 \mathrm{a}$ & $67.3 \mathrm{a}$ & $18.3 \mathrm{ab}$ & $63.1 \mathrm{ab}$ \\
\hline $2+5$ & $3.49 \mathrm{a}$ & $32.1 \mathrm{a}$ & $62.3 \mathrm{a}$ & $19.5 \mathrm{a}$ & $52.6 \mathrm{bc}$ \\
\hline $2+10$ & $3.49 \mathrm{a}$ & $33.0 \mathrm{a}$ & $68.4 \mathrm{a}$ & $16.4 \mathrm{bc}$ & $87.4 \mathrm{a}$ \\
\hline $11+10$ & $3.40 \mathrm{a}$ & $33.1 \mathrm{a}$ & $66.7 \mathrm{a}$ & $13.5 \mathrm{c}$ & $93.3 \mathrm{a}$ \\
\hline C.V. (\%) & 16.4 & 7.7 & 9.5 & 6.2 & 26.8 \\
\hline
\end{tabular}

Averages followed by the same letter in the columns were not different from one another according to the Tukey test $(\mathrm{p}<0.05)$. *Values $1,2,3$ and 4 for $0-25 \%, 26-50 \%, 51-75 \%$ and $>75 \%$ coverage of skin with red color, respectively.

The TA was higher in the fruit stored under CA than under CS upon leaving the chamber and after four days under ambient conditions (Table III). This result is in accordance with data produced by Brackmann et al. (2007), Sestari et al. (2008) and Singh and Singh (2013). Amongst the CA conditions, $1.0 \mathrm{kPaO}_{2}+3.0 \mathrm{kPa} \mathrm{CO}_{2}$ and $2.0 \mathrm{kPa}$ $\mathrm{O}_{2}+5.0 \mathrm{kPa} \mathrm{CO}$ provided the higher TA values, but were not different from the $1.0 \mathrm{kPa} \mathrm{O}_{2}+5.0 \mathrm{kPa}$ $\mathrm{CO}_{2}$ condition (Table III). The highest TA values under CA are probably due to the low respiration rate during storage under these conditions, since low partial pressures of $\mathrm{O}_{2}$ or high partial pressures of $\mathrm{CO}_{2}$ reduce the consumption of organic acids as a source of energy for the respiratory process (Steffens et al. 2007a, Sestari et al. 2008). 
The incidence of internal breakdown, a major physiological storage disorder in plums (Menniti et al. 2006), was higher under CA conditions with $10.0 \mathrm{kPa} \mathrm{CO}_{2}$ upon exiting the chamber (Table III). It was also observed in peaches and kiwis that the increase in the $\mathrm{CO}_{2}$ partial pressure caused an increase in the incidence of internal breakdown (Steffens et al. 2006 e 2007b). Conditions that cause a large reduction in the $\mathrm{O}_{2}$ partial pressure and/or intense increase in the $\mathrm{CO}_{2}$ partial pressure could be harmful to the tissue (Jayas and Jeyamkondan 2002), causing internal breakdown (Steffens et al. 2006). $\mathrm{CO}_{2}$ reduces the speed of the tricarboxylic acid cycle and, at extremely high levels, this reduction can induce the anaerobic metabolism and cause fermentation products to accumulate, causing physiological disorders. In pears internal breakdown was caused by the reduction of energetic metabolism and the content of phospholipids with further cell decompartmentalization (Saquet et al. 2003), so these changes could be related to internal breakdown in plum.

After four days of exposure to ambient conditions, the fruit treatments with $10.0 \mathrm{kPa}$ $\mathrm{CO}_{2}$ presented again a high incidence of internal breakdown, such as under $\mathrm{CS}$, which did not differ under the CA conditions of $1.0 \mathrm{kPa} \mathrm{O}_{2}+5.0 \mathrm{kPa}$ $\mathrm{CO}_{2}$ (Table III). The higher incidence of internal breakdown in the fruit stored under CS, compared to storage under the $\mathrm{CA}$ conditions of $1.0 \mathrm{kPa} \mathrm{O}$ $+3.0 \mathrm{kPa} \mathrm{CO}$ and $2.0 \mathrm{kPa} \mathrm{O}+5.0 \mathrm{kPa} \mathrm{CO}_{2}$ agrees with the results found in a study carried out with "Chiripá" peaches (Brackmann et al. 2003). Although the $1.0 \mathrm{kPa} \mathrm{O}+3.0 \mathrm{kPa} \mathrm{CO}_{2}$ and 2.0 $\mathrm{kPa} \mathrm{O}_{2}+5.0 \mathrm{kPa} \mathrm{CO}$ conditions presented lower incidence of internal breakdown, the incidence of the disorder was still considered high. Singh and Singh (2013) also observed lower internal breakdown in plums stored in CA.

No differences were observed between treatments for the contents of SS (data not shown).
The incidence of rottenness upon leaving the chamber was higher in the fruit stored under CS (data not shown). After four days of exposure of the fruit to ambient conditions, there were no significant differences between treatments. Regarding the fruit with cracking, only the ones stored under CS presented incidence corresponding to $20 \%$ upon leaving the chamber (data not shown).

In general, it was possible to verify that the CA, at the conditions assessed, presented excellent results in terms of delaying ripening. Even under these conditions, there was a high incidence of internal breakdown, the main limiting factor to the storage of 'Laetitia' plums under CA, which could compromise the quality of the fruit. As mentioned earlier, the incidence of this physiological disorder could be due to the reduction in energetic metabolism, the consequence of an intense limitation of aerobic respiration due to inappropriate combinations of $\mathrm{O}_{2}$ and $\mathrm{CO}_{2}$. Considering these facts, other studies must be carried out to assess the effect of combinations of $\mathrm{O}_{2}$ and $\mathrm{CO}_{2}$, in theory less restrictive to aerobic respiration ( 1 and $2 \mathrm{kPa} \mathrm{O}_{2}+<3 \mathrm{kPa} \mathrm{CO}_{2}$ ), on the incidence and intensity of internal breakdown.

\section{EXPERIMENT}

Before storage, the plums presented the following ripening attributes: flesh firmness of $44.2 \mathrm{~N}$, SS $9.1^{\circ}$ Brix and TA of $32.3 \mathrm{meq} 100 \mathrm{~mL}^{-1}$.

The respiration and ethylene production rates (data not shown), upon leaving the chamber, were lower in the fruit stored under CA than in the fruit stored under CS. After four days of ambient conditions, only the ethylene production rate presented difference between treatments, which was lower in the fruit stored under CA. Amongst the CA conditions, there were no differences for both variables and assessments.

The fruit stored under CS upon leaving the chamber and after four days of exposure to ambient conditions presented higher red color index (Table IV) and lower $h^{\circ}$ (data not shown), compared 
to the fruit stored under CA. This result evidences that fruit under CS presented more evolution of the skin red color. Amongst the $\mathrm{CA}$ conditions, storage under $1 \mathrm{kPa} \mathrm{O}_{2}+1 \mathrm{kPa} \mathrm{CO}$ and $2 \mathrm{kPa} \mathrm{O}_{2}+2 \mathrm{kPa}$ $\mathrm{CO}_{2}$ provided fruit with less evolution of skin red color in both assessments, apparently presenting less ripening of the fruit.
The flesh firmness and texture of the fruit kept under CS presented lower values (Table IV). Overall, amongst the $\mathrm{CA}$ conditions, storage under $1 \mathrm{kPa} \mathrm{O}_{2}+0 \mathrm{kPa} \mathrm{CO}$ provided the worst results in the maintenance of flesh firmness and texture attributes. The CA conditions of 1 $\mathrm{kPaO}_{2}+1 \mathrm{kPaCO}$ and $2 \mathrm{kPaO}_{2}+2 \mathrm{kPaCO}$

TABLE IV

Red color index (RCI), flesh firmness, texture attributes and titratable acidity in 'Laetitia' plums stored at $0.5^{\circ} \mathrm{C}$ under different atmospheres for 60 days and four additional days under ambient conditions $\left(20 \pm 2^{\circ} \mathrm{C} / 60 \pm 5 \% \mathrm{RH}\right)$, Lages, SC, Brazil, 2011.

\begin{tabular}{|c|c|c|c|c|c|}
\hline \multirow{2}{*}{$\begin{array}{c}\text { Atmosphere } \\
\mathrm{O}_{2}+\mathrm{CO}_{2}(\mathrm{kPa})\end{array}$} & \multirow{2}{*}{$\begin{array}{l}\mathrm{RCI} \\
(1-4)\end{array}$} & \multirow{2}{*}{$\begin{array}{c}\text { Flesh } \\
\text { firmness }(\mathrm{N})\end{array}$} & \multicolumn{2}{|c|}{ Texture attributes } & \multirow{2}{*}{$\begin{array}{l}\text { Titratable acidity } \\
\left(\mathrm{meq} 100 \mathrm{~mL}^{-1}\right)\end{array}$} \\
\hline & & & $\begin{array}{l}\text { Flesh penetration } \\
\text { force }(\mathrm{N})\end{array}$ & $\begin{array}{c}\text { Fruit compression } \\
\text { force }(\mathrm{N})\end{array}$ & \\
\hline & \multicolumn{5}{|c|}{ Chamber outlet } \\
\hline $21+0.03$ & $3.60 \mathrm{a}$ & $22.53 \mathrm{e}$ & $1.12 \mathrm{c}$ & $52.37 \mathrm{~d}$ & $11.86 \mathrm{c}$ \\
\hline $1+0$ & $3.11 \mathrm{~b}$ & $28.11 \mathrm{~d}$ & $1.53 \mathrm{~b}$ & $108.04 \mathrm{c}$ & $16.02 b$ \\
\hline $1+1$ & $2.78 \mathrm{c}$ & $41.44 b$ & $2.60 \mathrm{a}$ & $131.47 b$ & $18.57 \mathrm{ab}$ \\
\hline $2+1$ & $3.03 \mathrm{~b}$ & $35.96 \mathrm{c}$ & $2.23 \mathrm{a}$ & $123.90 \mathrm{~b}$ & $17.84 \mathrm{ab}$ \\
\hline $2+2$ & $2.80 \mathrm{c}$ & $45.87 \mathrm{a}$ & $2.62 \mathrm{a}$ & $157.54 \mathrm{a}$ & $19.06 \mathrm{a}$ \\
\hline \multirow[t]{2}{*}{ CV (\%) } & 5.14 & 6.67 & 12.80 & 7.65 & 11.27 \\
\hline & \multicolumn{5}{|c|}{ After 4 days of shelf life } \\
\hline $21+0.03$ & $3.80 \mathrm{a}$ & $26.70 d$ & $1.05 \mathrm{~b}$ & $70.53 \mathrm{c}$ & $11.31 \mathrm{c}$ \\
\hline $1+0$ & $3.36 \mathrm{bc}$ & $29.67 \mathrm{~cd}$ & $1.24 b$ & $125.92 b$ & $15.00 \mathrm{~b}$ \\
\hline $1+1$ & $3.27 \mathrm{c}$ & $42.03 \mathrm{a}$ & $2.14 \mathrm{a}$ & $181.48 \mathrm{a}$ & $18.02 \mathrm{a}$ \\
\hline $2+1$ & $3.53 \mathrm{~b}$ & $35.80 \mathrm{bc}$ & $1.94 \mathrm{a}$ & $174.68 \mathrm{a}$ & $17.60 \mathrm{a}$ \\
\hline $2+2$ & $3.40 \mathrm{bc}$ & $38.55 \mathrm{ab}$ & $2.15 \mathrm{a}$ & $176.00 \mathrm{a}$ & $17.53 \mathrm{a}$ \\
\hline CV $(\%)$ & 4.80 & 11.76 & 11.67 & 6.07 & 12.50 \\
\hline
\end{tabular}

Averages followed by the same letter in the columns were not different from one another according to the Tukey test ( $\mathrm{p}<0.05)$.

presented the highest values of flesh firmness. Regarding the forces for flesh penetration and fruit compression, the highest values were obtained in the fruit stored under $1 \mathrm{kPa} \mathrm{O}_{2}+1$ $\mathrm{kPa} \mathrm{CO}, 2 \mathrm{kPa} \mathrm{O}+1 \mathrm{kPa} \mathrm{CO}$ and $2 \mathrm{kPa} \mathrm{O}_{2}$ $+2 \mathrm{kPa} \mathrm{CO}$. Combinations of low $\mathrm{O}_{2}$ and high $\mathrm{CO}_{2}$ keep the flesh firmness and texture, since they reduce the activity of hydrolytic enzymes responsible for the degradation of cell wall components, besides acting in the reduction of the ethylene biosynthesis and action (Majumder and Mazumdar 2002).
The highest TA values were found in the fruit stored under the CA conditions with $1 \mathrm{kPa} \mathrm{O}_{2}+$ $1 \mathrm{kPa} \mathrm{CO}, 2 \mathrm{kPa} \mathrm{O}_{2}+1 \mathrm{kPaCO}$ and $2 \mathrm{kPaO}_{2}+$ $2 \mathrm{kPa} \mathrm{CO}_{2}$, and the lowest values were found in the fruit stored under CS (Table IV). These results are in accordance with Steffens et al. (2007a), Sestari et al. (2008) and Singh and Sing (2013), who observed that $\mathrm{CA}$ conditions with higher partial pressures of $\mathrm{CO}_{2}$ reduce the consumption of organic acids in stored fruit.

Regarding the incidence of rottenness and cracking, the fruit stored under CS presented higher 
values than the ones stored under CA. There were no differences between the CA conditions (Table V). The effects of CA on the reduction of rottenness incidence can be attributed to the increase in physical resistance of the fruit tissues, evidenced mainly by the firmer flesh due to the effect of gases in delaying ripening. The occurrence of cracking in fruit stored under CS is strongly related to the excessive ripening of the fruit (Brackmann et al. 2008).

The incidence of internal breakdown upon leaving the chamber was lower in the fruit stored under $1 \mathrm{kPa} \mathrm{O}_{2}$ combined with 0 and $1 \mathrm{kPa}$
$\mathrm{CO}_{2}$, and it was not different from the other CA conditions (Table V). After four days under ambient conditions, there were no differences between the storage conditions assessed. In all treatments and both assessment periods, the incidence of the physiological disorder was high ( $>88 \%$ ). According to Alves et al. $(2009,2010)$, the susceptibility of 'Laetitia' plums to this disorder represents its main postharvest loss.

In spite of the high incidence of internal breakdown in all storage conditions, the fruit stored under $2 \mathrm{kPa} \mathrm{O}_{2}$ combined with 1 and $2 \mathrm{kPa} \mathrm{CO}_{2}$

TABLE V

Incidence of rottenness, cracking and internal breakdown and color $(L)$ in 'Laetitia' plums stored at $0.5^{\circ} \mathrm{C}$ under different atmospheres for 60 days and four days under ambient conditions $\left(20 \pm 2^{\circ} \mathrm{C} / 60 \pm 5 \% \mathrm{RH}\right)$, Lages, SC, Brazil, 2011.

\begin{tabular}{c|cccc}
\hline \multicolumn{1}{c}{$\begin{array}{c}\text { Atmosphere } \\
\mathrm{O}_{2}+\mathrm{CO}_{2}(\mathrm{kPa})\end{array}$} & Rottenness $(\%)$ & Cracking $(\%)$ & Internal breakdown (\%) & Flesh color $(L)$ \\
\hline & & & Chamber outlet & $40.10 \mathrm{~b}$ \\
$21+0.03$ & $50.0 \mathrm{a}$ & $82.5 \mathrm{a}$ & $100 \mathrm{a}$ & $30.28 \mathrm{c}$ \\
$1+0$ & $1.9 \mathrm{~b}$ & $0.7 \mathrm{~b}$ & $88.5 \mathrm{~b}$ & $43.33 \mathrm{~b}$ \\
$1+1$ & $2.8 \mathrm{~b}$ & $0.7 \mathrm{~b}$ & $87.5 \mathrm{~b}$ & $48.33 \mathrm{a}$ \\
$2+1$ & $10.0 \mathrm{~b}$ & $0.7 \mathrm{~b}$ & $92.7 \mathrm{ab}$ & $48.70 \mathrm{a}$ \\
$2+2$ & $2.5 \mathrm{~b}$ & $0.7 \mathrm{~b}$ & $95.0 \mathrm{ab}$ & 2.84 \\
$\mathrm{CV}(\%)$ & 28.5 & 29.76 & 8.34 & $40.33 \mathrm{~b}$ \\
$21+0.03$ & & & After 4 days of shelf life & $33.53 \mathrm{c}$ \\
$1+0$ & $48.2 \mathrm{a}$ & $93.6 \mathrm{a}$ & $96.4 \mathrm{a}$ & $41.61 \mathrm{~b}$ \\
$1+1$ & $22.1 \mathrm{~b}$ & $0.0 \mathrm{~b}$ & $93.3 \mathrm{a}$ & $48.1 \mathrm{a}$ \\
$2+1$ & $15.1 \mathrm{~b}$ & $1.3 \mathrm{~b}$ & $97.4 \mathrm{a}$ & $91.2 \mathrm{a}$ \\
$\mathrm{CV}(\%)$ & $10.7 \mathrm{~b}$ & $0.0 \mathrm{~b}$ & 11.73 & $48.02 \mathrm{a}$ \\
\hline
\end{tabular}

Averages followed by the same letter in the columns were not different from one another according to the Tukey test ( $\mathrm{p}<0.05)$.

presented, in both assessments, a higher $L$ value in the flesh, which characterizes a lower intensity of internal breakdown (Table V). According to Corrêa et al. (2011), 'Laetitia' plums with internal breakdown can present good acceptability by the consumer if the disorder is in the initial phase of development. These authors verified that fruit with $L$ value in the flesh equal to 48.7 , similar to the ones observed in this study, in the $2 \mathrm{kPa} \mathrm{O}_{2}$ combined with 1 and $2 \mathrm{kPa} \mathrm{CO}_{2}$ treatments presented acceptability above $50 \%$ in terms of skin color. On the other hand, fruit with $L$ values in the flesh of 41.3, above the one observed in the fruit stored under $\mathrm{CS}$ and $1 \mathrm{kPa} \mathrm{O}_{2}+1 \mathrm{kPa} \mathrm{CO}_{2}$, present $95 \%$ of rejection in terms of flesh color. Thus, the storage of 'Laetitia' plums under $2 \mathrm{kPa} \mathrm{O}_{2}$ combined with 1 and $2 \mathrm{kPa} \mathrm{CO}_{2}$, in spite of the high incidence of internal breakdown, provides a delay in the fruit ripening and satisfactory acceptability due to the less intense internal breakdown. It is worth noting that the cold storage period used in this study (60 days, followed by four days under ambient conditions), even under CA, may be too long a period for 'Laetitia' plums. 
The storage under controlled atmosphere (CA) with 1 to $2 \mathrm{kPa} \mathrm{O}_{2}+1$ to $3 \mathrm{kPaCO}_{2}$ presents the best results in terms of delaying ripening of 'Laetitia' plums, although with high incidence of internal breakdown. The recommended CA condition for storing 'Laetitia' plums is $2 \mathrm{kPa} \mathrm{O}_{2}+2 \mathrm{kPa} \mathrm{CO}$, since it allows for a slower apparent ripening of the fruit (lower evolution of the skin red color) and low intensity of internal breakdown.

\section{ACKNOWLEDGMENTS}

The authors thank the Conselho Nacional de Desenvolvimento Científico e Tecnológico (CNPq), the Fundação de Amparo à Pesquisa e Inovação do Estado de Santa Catarina (FAPESC) and the Programa de Apoio à Pesquisa da Universidade do Estado de Santa Catarina (PAP-UDESC) for the financial support provided for the project.

\section{RESUMO}

O objetivo deste trabalho foi avaliar o efeito de condições de atmosfera controlada (AC) sobre a manutenção das qualidades de ameixas 'Laetitia', especialmente sobre a incidência do escurecimento de polpa, e identificar a condição de AC ideal. Foram conduzidos dois experimentos nos anos de 2010 e 2011. No ano de 2010, além do armazenamento refrigerado (AR; 21,0 $\mathrm{kPa} \mathrm{O}{ }_{2}+0,03 \mathrm{kPa} \mathrm{CO}$ ), foram avaliadas as seguintes condições de $\mathrm{AC}\left(\mathrm{kPa} \mathrm{O}_{2}+\mathrm{kPa}\right.$ $\mathrm{CO}_{2}$ ): $1+3,1+5,2+5,2+10$, e $11+10$. No experimento de 2011 foram avaliados os seguintes tratamentos: AR, $1+0,1+1,2+1$, e $2+2$. Os frutos armazenados em AC apresentaram menores taxas respiratórias e de produção de etileno, melhor preservação da firmeza de polpa, atributos de textura e acidez titulável e menores valores de cor vermelha da casca e de incidência de rachaduras, comparativamente aos frutos mantidos em AR. No experimento de 2010, as condições de AC de $2+5,1+5$ e $1+3$ apresentaram redução do amadurecimento, embora com elevada incidência de escurecimento da polpa. No experimento de 2011, AC com $2+1$ e $2+2$ proporcionaram maior retardo do amadurecimento e menor intensidade do escurecimento de polpa. Conclui-se que a melhor condição de $\mathrm{AC}$ para o armazenamento de ameixas 'Laetitia' a $0,5^{\circ} \mathrm{C}$ é $2 \mathrm{kPaO}_{2}+2 \mathrm{kPaCO}$.

Palavras-chave: Prunus salicina, pós-colheita, amadurecimento, distúrbio fisiológico.

\section{REFERENCES}

Alves EO, STEFFEns CA, AMARANTE CVT AND BRACKMANN A. 2010. Qualidade de ameixas 'Laetitia' em função da temperatura e da atmosfera de armazenamento. R Bras Frutic 32: 1018-1027.

Alves EO, Steffens CA, Amarante CVT, Pavanello EP AND BRACKMANN A. 2009. Manejo do etileno durante o armazenamento de ameixas 'Laetitia' em atmosfera controlada. Ciênc Rural 39: 2445-2451.

Argenta LC, Krammes JG, Megguer CA, Amarante CVT AND MATTHEIS J. 2003. Ripening and quality of 'Laetitia' plums following harvest and cold storage as affected by inhibition of ethylene action. Pesq Agropec Bras 38: 139-1148.

BAnKs NH, Cleland DJ, CAMERON AC, BEANDRY RM AND KADER AA. 1995. Proposal for a rationalized system of units for postharvest research in gas exchange. HortSci 30: 1129-1131.

BLANKENSHIP SMAND DOLE JM. 2003. 1-Methylcyclopropene: a review. Postharvest Biol Technol 28: 1-25.

Brackmann A, Bordignon BCS, Giehl RFH, Sestari I AND EISERMANN AC. 2007. Armazenamento de pêssegos cv. Granada em atmosfera controlada, visando ao transporte a longas distâncias. Ciênc Rural 37: 676-681.

Brackmann A, StefFens CA AND GIEHL RFH. 2003. Armazenamento de pêssegos 'Chimarrita' em atmosfera controlada e sob absorção de etileno. Ciênc Rural 33: 431-435.

Brackmann A, Weber A, Pinto JAV, NeUwAld DA AND STEFFENSCA. 2008. Manutenção da qualidade pós-colheita de maçãs 'Royal Gala' e 'Galaxy' sob armazenamento em atmosfera controlada. Ciênc Rural 38: 2478-2484.

CorrêA TR, StefFens CA, TANaKa H, Amarante CVT, BRACKMANN A AND ANESE RO. 2011. Ameixas 'Laetitia' armazenadas em atmosferas controlada e modificada ativa com manejo do etileno. Rev Bras Frutic 33: 723-729.

FONSECA SC, OLIVEIRA FAR AND BRECHT JK. 2002. Modelling respiration rate of fresh fruits and vegetables for modified atmosphere packages: a review. J Food Eng 52: 99-119.

JAYAS DS AND JEYAMKONDAN S. 2002. Modified atmosphere storage of grains, meats, fruits and vegetables. Biosystems Eng 82: 235-251.

MAJUMdER K AND MAZUMDAR BC. 2002. Changes of pectic substances in developing fruits of cape-gooseberry (Physalis peruviana L.) in relation to the enzyme activity and evolution of ethylene. Scient Hort 96:91-101. 
MENNITI AM, DONATI I AND GREGORI R. 2006. Responses of 1-MCP application in plums stored under air and controlled atmospheres. Postharvest Biol Technol 39: 243-246.

SAquet AA, Streif J AND BAngerth F. 2003. Energy metabolism and membrane lipid alterations in relation to brown heart development in 'Conference' pears during delayed controlled atmosphere storage. Postharvest Biol Technol 30: 123-132.

Sestari I, Giehl RFH, Pinto JAV AND BRACKMANN A. 2008 Condições de atmosfera controlada para pêssego 'Maciel' colhidos em dois estádios de maturação. Ciênc Rural 38: 1240-1245.

SINGH SP AND SINGH Z. 2012. Postharvest oxidative behaviour of 1-methylcyclopropene treated Japanese plums (Prunus salicina Lindell) during storage under controlled and modified atmospheres. Postharvest Biol Technol 74: 141-145.

SingH SP AND SINGH Z. 2013. Controlled and modified atmospheres influence chilling injury, fruit quality and antioxidative system of Japanese plums (Prunus salicina Lindell). Intern J Food Sc Technol 48: 363-374.
StefFens CA, Amarante CVT, Alves EO, TANaka H BRACKMANN A AND Both V. 2009. Armazenamento de ameixas 'Laetitia' em atmosfera modificada. Ciênc Rural. 39: 2439-2444.

STEFFENS CA, BRACKMANN A, LOPES SJ, PINTO JAV, EISERMANN AC, GIEHL RFH AND WEBER A. 2007b. Degenerescência da polpa e respiração de quivi cv. Bruno em função das condições de armazenamento. Ciênc Rural 37: 1621-1626.

STEFFENS CA, BRACKMANN A, PINTO JAV AND EISERMANN AC. 2006. Escurecimento da polpa e respiração de pêssegos em função das condições de armazenamento. R Bras Agroc 12: 71-75.

StefFENS CA, BRACKMANN A, PINTO JAV AND EISERMANN AC. 2007a. Taxa respiratória de frutas de clima temperado. Pesq Agropec Bras 42: 313-321.

STREIF J. 1995. Lagerung von Stein und Beerebobst. BesseresObst 4: 18-19.

VAN DE GEIJN F. 1993. Meer duidelijkheid gewenst alvorens te investeren in CA-bevaring. Fruitt 25: 20-21. 